\title{
WATER LEVEL FLUCTUATION IN KARST AQUIFERS IN THE TRANSDANUBIAN RANGE (HUNGARY)
}

\author{
${ }^{1}$ Márton MALLER, ${ }^{2}$ András REHÁK, ${ }^{3}$ Géza HAJNAL \\ ${ }^{1}$ North-Transdanubian Water Directorate, Árpád út 28-32, H-9021 Győr, Hungary \\ e-mail: maller.marton@eduvizig.hu \\ ${ }^{2,3}$ Department of Hydraulic and Water Resources Engineering, Budapest University of \\ Technology and Economics, Müegyetem rkp, 3, H-1111 Budapest, Hungary \\ e-mail: ${ }^{2}$ rehak.andras@epito.bme.hu, ${ }^{3}$ hajnal.geza@epito.bme.hu
}

Received 30 December 2017; accepted 28 May 2018

\begin{abstract}
Monitoring of the karst aquifers of Transdanubian Range gives an opportunity to analyze not only the long-term water level and spring discharge changes, but also the short-term fluctuations. In this paper observations related to increasing karst water level in the region of Tata are presented. Short-term karst water level fluctuations are compared to the monitoring wells near Tata and data series of the Molnár János-Cave in Budapest. By the help of available water level data the periodic fluctuation of the karst water surface is identified in connection with tidal effect and the influence of barometric pressure.
\end{abstract}

Keywords: Transdanubian range, Karst aquifer, Tata, Tidal effect, Water level, Spring discharge, Molnár János Cave

\section{Introduction}

The Transdanubian Range is located in the North-Western part of Hungary. Forming a large NE-SW-trending synform, it is predominantly made up of Middle and Upper Triassic shallow-marine carbonates [1]. In this region Dachstein-type platform carbonates developed with a remarkable areal extension and thickness [2]. In the Middle Triassic an extensional tectonic regime was established, which led to the development of carbonate platforms and basins in the area of the Transdanubian Range [3]. One of the discharge zones of the Transdanubian Range is the region of Tata, which is situated in the valley of a stream called Által-ér, which is surrounded by the karst aquifers. Until the middle of the $20^{\text {th }}$ century there used to be many springs in the city of Tata but after 1950 all of the springs dried up as a consequence of coal mining in the region of 
Tatabánya (Fig. 1), which had been begun in 1896 [4]. In the 1940-50's the level of brown coal's exploitation reached the karst water table, so active and passive lowering of water levels became technically necessary [5]. As a consequence of intensive mine dewatering the karst water table decreased tens of meters at several parts of the Transdanubian Range. After the springs had disappeared, decision-makers of the city did not take into consideration that the state of the karst aquifer would change in the future. Drainage trenches had been filled and low-lying gardens became built-up areas. In 1990 the mines were abandoned, since then there was no demand to extract water because of mining activity. After the ceasing of coal mines the recharging process of the karst aquifer has begun, thus the water levels in the whole region has increased more than 40 meters from the year of 1991 until today. Nowadays the level of karst water is permanently rising, and the old springs return one after the other at several places of the city. Unfortunately water appears in the built-up area as well, which has harmful effects on built environment and causes many problems to the proprietors (appearing water in gardens or basements, stability and corrosion problem of structures, overloading of the rainwater's drainage system).

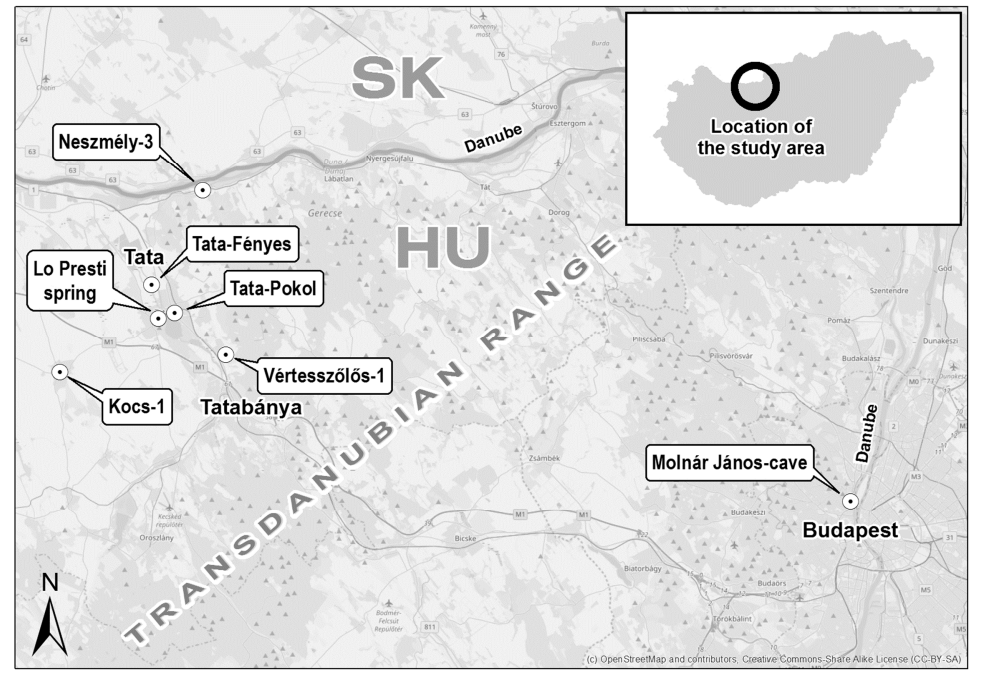

Fig. 1. Map of the target area and the investigated monitoring points

The aim of the research is to explore and classify the recharging processes of karst aquifers based on the measurements and experiences related to the observed phenomena near Tatain order to assess the qualitative and quantitative alterations of the water body. This information is especially important not only from the viewpoint of the effects of returning karst water, but also from the artificial water utilization aspect. In Hungary $14.9 \%$ of the drinking water is exploited from karst aquifers [6]. In this paper the results of the long-term analysis related to the karst water levels of the Transdanubian Range are introduced and the short-term, daily surface fluctuations are evaluated. The available 
time series are compared with another water level series, which has been detected in other separated karst aquifer system at the same time period.

\section{Long-term changes of karst water levels}

During the analysis of the time series water level data was used, which were registered in those monitoring wells where the observation time period was long enough to implement the investigations. An additional criterion was that the accuracy of the water level measurement and the registration time step had to be in line with the demands of the long-and short-term analysis. The location of the selected karst water level monitoring wells and the target area in the broad sense are visualized in Fig. 1.

To evaluate the long-term water level changes observed data series of springs and monitoring wells situated in Tata (Tata-Fényes, Tata-Pokol, Lo Presti spring) and in different settlements near Tata (Kocs-1, Vértesszőlős-1, Neszmély-3) were applied. According to the available karst water level series it can be demonstrated that the depression of water surface caused by the intensive mine dewatering then the recharging process took place with similar velocity and scale in the whole discharge zone of the karst system. Karst water levels registered in different monitoring wells followed each other in parallel during the entire investigated period (between 1970 and 2017), thus one water level data series could be chosen to represent the water level changes in the region. This water level data series belong to the 'Tata-Pokol' well. Therefore this monitoring well is examined in this paper.

The intensity of discharge and recharge period was analyzed on comprehensive way by utilization of the entire available one hour density time series. In Fig. 2 monthly average karst water levels of the 'Tata-Pokol' monitoring well are plotted with the trend of long-term changes. According to the equation of the trend lines the gradient of the monthly water level increase or decrease can be specified.

The equation of the average velocity of the discharge period ( $y$ is the water level calculated in the $x^{\text {th }}$ month of the whole data series in meters above Baltic Sea level):

$$
y=-0.1151 \cdot x+125.15
$$

The equation of the average velocity of the increasing water level during the recharge period:

$$
y=0.1408 \cdot x+61.88 \text {. }
$$

The comparison of the long-term karst water level changes resulted that the gradient of the trend lines had the opposite sign but similar absolute value. This means that the artificial large-scale discharge period and the natural recharging process took place with approximately similar intensity while the recharge period was a little bit faster. Water level changes in the system due to long-term mine dewatering, exemplify the hydraulic continuity and compartmentalization of the karst system on the basin scale [7]. 


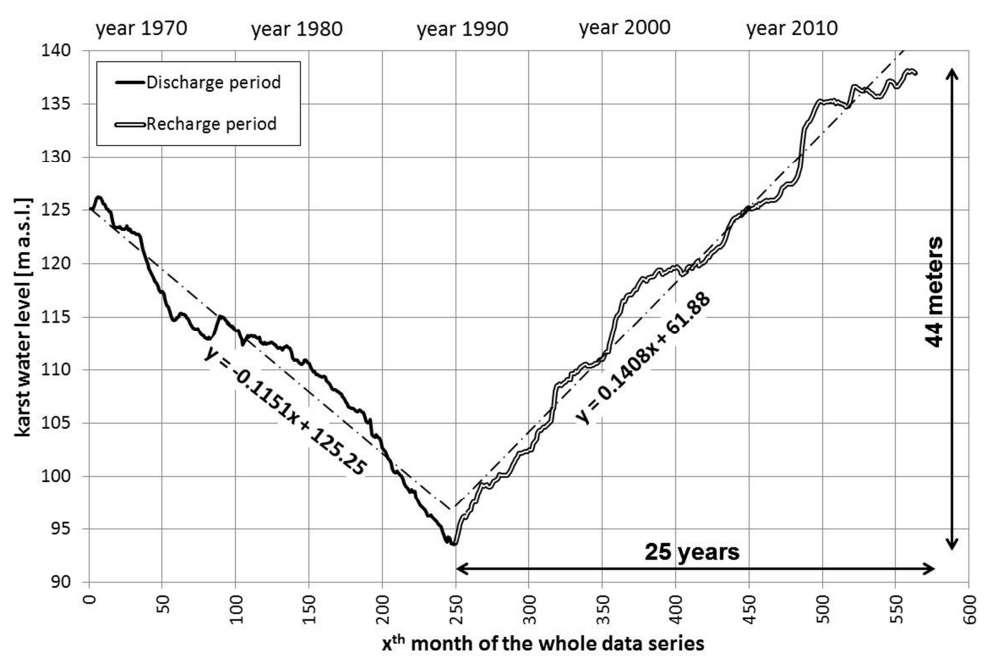

Fig. 2. Velocity of long-term karst water level changes during the whole available period

According to the evaluation of the available karst water level series it can be seen that the increase or decrease of water levels was transient during the whole period. In some shorter periods of the varying mining water extractions and the natural alteration of water supply results different water level decrease or increase compared with the average velocity. In Fig. 3 the weekly water level changes of the 'Tata-Pokol' monitoring well was construed for the entire recharge period (between 1991 and 2017).

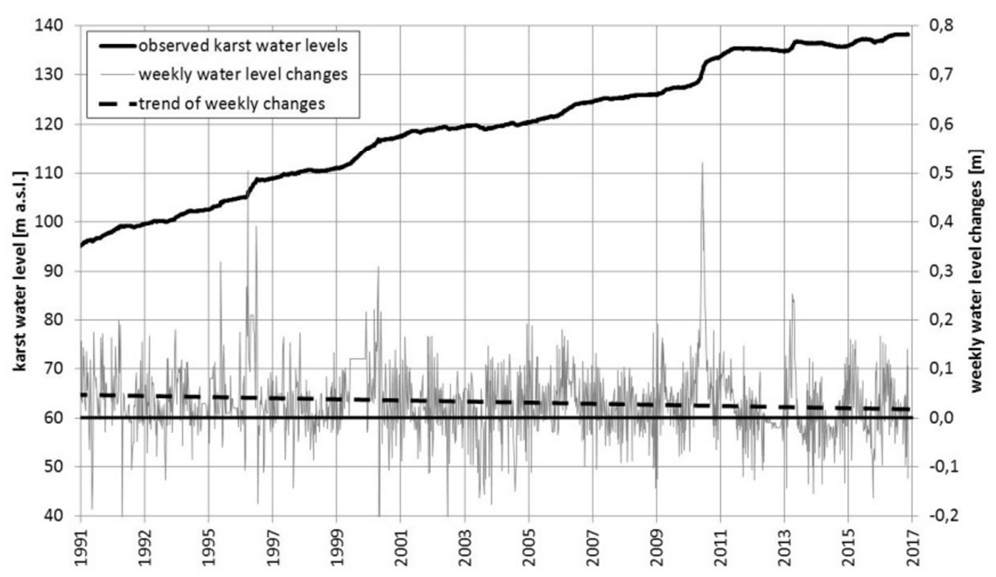

Fig. 3. Weekly karst water level changes during the entire recharge period

Fig. 3 highlights the emerging absolute karst water levels and the one of weekly changes, that the recharge of karst aquifers was faster in some shorter periods. According to the available data of precipitation monitoring stations situated in the 
infiltration area in this periods $(1996,2010,2013)$ precipitation amount was significantly larger than the average (e.g. between 1994 and 2012 the average precipitation amount of 'Tatabánya' precipitation monitoring station was $671 \mathrm{~mm} /$ year, but in 2010 this value was $1112 \mathrm{~mm}$ ). The situation is similar during the summer periods, which were drier than the average. In this weeks or months constant curve sections were found in the graph, or in several cases decreasing karst water levels were experienced.

During the investigation of the intensity of the recharging process not only the locally significant alterations were analyzed but also the global trend of the karst water level changes. When linear trend was edited to the entire data series of the recharge period it was not surprising that the adjusted line was situated in the positive range: the karst aquifer of the Transdanubian Range is recharging permanently. It is more interesting that the long-term analysis resulted in regressive intensity of recharge, therefore the recharging process of the karst aquifer is getting slower. In the early 1990's the average increase of the karst water level was $5 \mathrm{~cm}$ a week, nowadays this value is about $2 \mathrm{~cm}$ a week.

As it was mentioned earlier the karst water levels of different monitoring wells in the region followed each other closely in parallel during the whole investigated period, despite the fact that some wells are located far away from each other (distance between Kocs and Neszmély is about $20 \mathrm{~km}$ ). Nevertheless the deviation of karst water levels belonging to the same time was not steady during the discharge and recharge period. In Fig. 4 deviation from average water level of the investigated monitoring wells is shown. The deviations are smaller in the low water regime than the deviations concerning the original state of the karst aquifer.

Nowadays the deviation of karst water levels registered in the examined area is more than 1 meter. Higher water levels belong to the 'Vértesszölös-1' monitoring well, which is located closer to the infiltration area. Lower piezometric levels belong to the 'Neszmély-3' monitoring well situated in the discharge zone, near river Danube (Fig. 1). This piezometric pressure difference ensures the underground flow of karst water, which has typically south-north orientation in the whole discharge zone. The state of karst water levels in the region used to be similar before the 1970's, when mine dewatering had no significant effect on karst water resources yet. During the next 20 years the deviation of karst water levels decreased continuously as well as absolute water levels, the piezometric pressure levels were equalized in the region. In the year 1990 deviation from average water level was under 0.5 meters. This means that in the end of the discharge period (which is equal to the beginning of recharge period) the flow of karst water under the investigated area slowed down and the piezometric pressure level was about 40 meters deeper than the karst water level of the natural state, without significant slope of the water surface.

From the end of the 1980's until now many papers and studies dealt with the issue of the changing karst water levels related to mine dewatering in the Tatabánya region. The scope of these investigations also concerned the estimation of the recharging velocity of the karst aquifer; more forecasts were published in connection with the increasing karst water levels of the examined area. Water Resources Research Centre (VITUKI) gave forecasts for 6 different scenarios in the study published by Gerber P. in 1989 [8]. In this paper the rising of karst water levels was estimated for different time periods 
according to different hydrological conditions. Ten years later a mathematical model was created by Hydrosys Ltd, [9], which was suitable for the analysis of pressure changes of the Transdanubian Range's entire karst system. By the help of this numeric model a forecast was calculated for the period until 2040, which served with basic information to establish the Action Program [9] in the topic of managing problems related to increasing karst water level and returning springs in the city of Tata. Szilágyi et al. (2015) compared the different water level forecasts mentioned above with the observed karst water level series, which were registered since then in their paper [10]. To assess the accuracy of the different forecasts the correlations of the observed and the estimated data series of 3 selected monitoring wells were calculated. The conclusion of the study was that the former forecasts proved to be very accurate; the calculated correlation coefficients were between 0.93 and 0.98 . The result of this comparative analysis gives an opportunity to apply the most advanced estimation during the further investigations related to the recharging process of the karst aquifers.

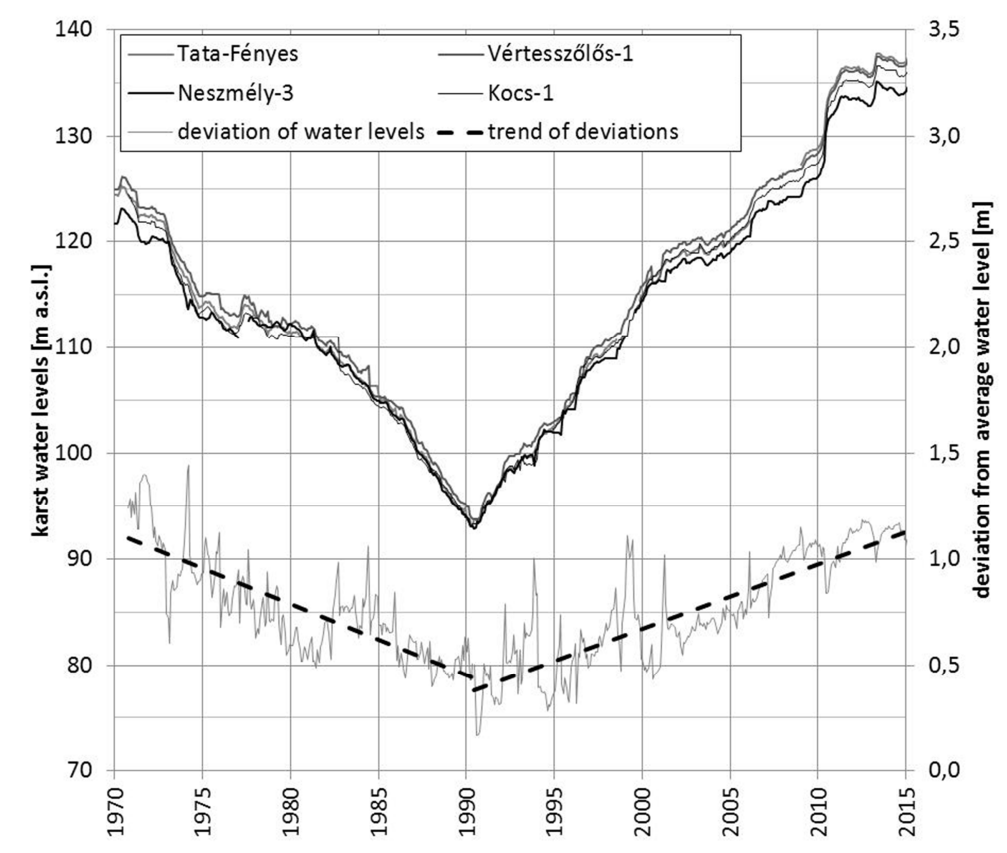

Fig. 4. Deviation of karst water levels in different monitoring wells

\section{Short-term fluctuations of karst water levels}

As analyzing the long-term changes of the karst water levels of Transdanubian Range short-term fluctuations were observed as well. This alteration can be seen in Fig. 5. The graph shows the karst water levels of 'Lo Presti' spring from April to July in 2012. T The periodic daily fluctuation does not depend on the trend of recharging process or the 
precipitation it is detectable in any time interval of the available karst water level data series. This phenomenon of 'Lo Presti' spring recognized in time series has similarity with the tidal effect and the influence of barometric pressure.

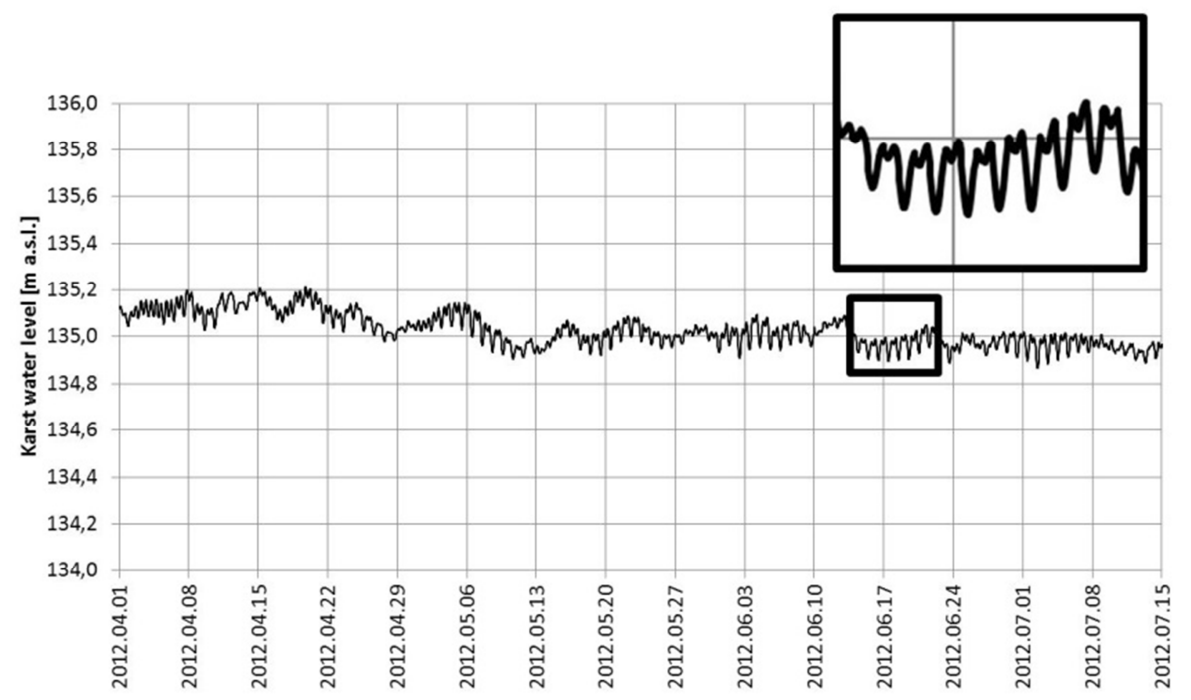

Fig. 5. Short-term water level fluctuation of 'Lo Presti' spring

The aim of the following part of this paper is to confirm that the short-term fluctuations can be identified in data series of any monitoring wells, and the periodic alteration describes the daily water level changes of the whole karst aquifer system.

The basic criteria of the analysis of the short-term water level fluctuations is applying observed raw data series, which are accurate enough to identify slight water level changes in a few centimeters range. Another required criterion is the high frequency of the input data: karst water level data series are needed with one hour time step at least to carry out the hydrological analysis. In Fig. 6 the karst water level curves of two monitoring wells are shown, which satisfied the required conditions, the graph belongs to a shorter three-day related period. It can be seen that the one-hour data of the monitoring wells follows each other in parallel with approximately $13 \mathrm{~cm}$ constant difference. It is also notable that the amplitude of the daily fluctuations registered in monitoring wells called 'Tata-Pokol' and 'Kocs-1' is about $10 \mathrm{~cm}$. This value equals to Gerber's observations [11]. Gerber evaluated karst water level series of a monitoring well called 'Tatabánya No. 1 borehole' between 1964 and 1965, and described the scale of periodic water level fluctuation related to tidal effect in 10-12 centimeters.

The main purpose of the hydrological analysis was giving a mathematical description of periodic fluctuation of observed data in order to compare the return time and the local extremes of short-term water table changes in different karst aquifers. To evaluate numerically the daily alteration three different monitoring wells were chosen, which were equipped with appropriate devices (provided data series with high accuracy 
and time step). Short-term water level fluctuation was analyzed not only related to the karst water body represented by 'Tata-Pokol' and 'Kocs-1' monitoring wells but also another karst system represented by data series of Molnár János-Cave. The aim of expansion of the investigation area was to prove that tidal and barometric effects traceable in water levels of either another karst aquifers. In the interest of comparability the investigation was carried out for the same random time period (May 14-17, 2015) in case of all the three monitoring places. The Molnár János-Cave belongs to Europe's largest naturally flowing thermal water system, the hot spring and wells that supply the baths of Budapest, is discharging from Triassic carbonate rocks. Many caves and related phenomena can be observed in the 'Buda Karst' [12]. This area is situated approximately 55-60 km distance from the monitoring wells in the surroundings of Tata (a different karst aquifer), thus there is no direct connection between the short-term water level changes.

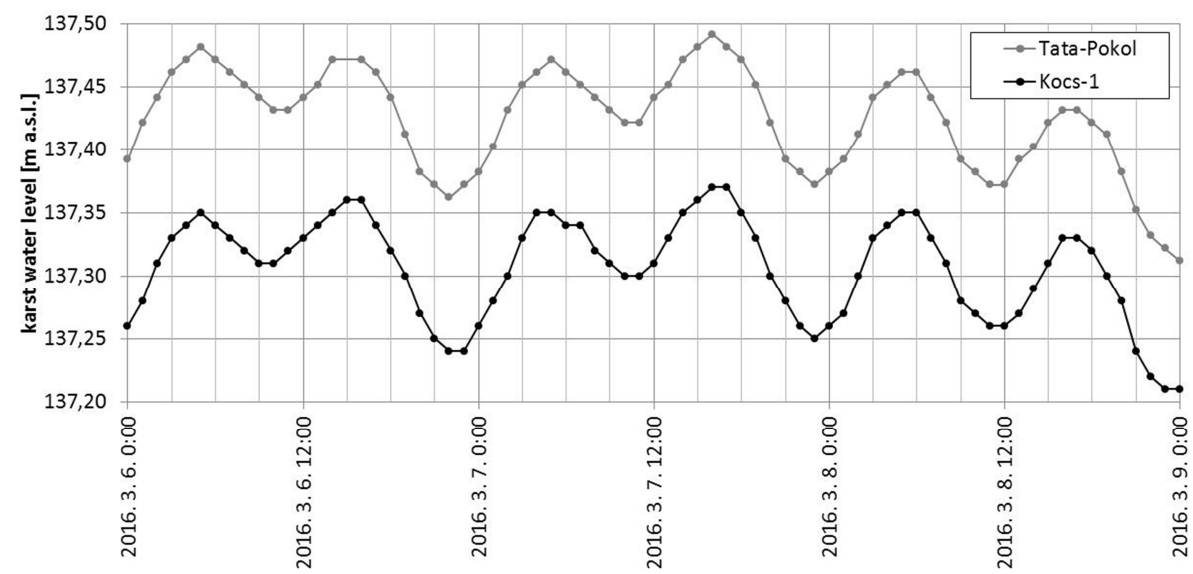

Fig. 6. Observed raw data series of 'Tata-Pokol' and 'Kocs-1' monitoring wells

Utilizing hydrological analysis the deterministic components of available data series can be specified, thus a mathematical description of short-term karst water level fluctuations can be given. During the investigation hourly data of the three-day long time series were applied, so the calculation was based on 72 observed data record in case of each monitoring wells. The hydrological analysis was performed with the methodology of Kontur at al. [13].

First the trend-free data series were specified as a subtraction of originally observed karst water levels and then calculated $T_{i}$ value belonging to the trend line. The $a_{0}$ and $a_{1}$ coefficients of the linear trend were specified by the help of least-squares method:

$$
T_{i}=a_{0}+a_{1} \cdot i
$$

Later on a periodic function was defined, which fits well with the trend-free water level time series. The general form of these functions can be described with the 
following formula $\left(k_{s}\right.$ and $k_{c}$ coefficients specify the amplitude of the water level alteration; return time is indicated by $T$ ),

$$
P_{i}=k_{s} \cdot \sin \left(2 \pi \cdot \frac{i}{T}\right)+k_{c} \cdot \cos \left(2 \pi \cdot \frac{i}{T}\right),
$$

where

$$
\begin{aligned}
& k_{s}=\frac{2}{n} \cdot \sum_{i=1}^{n} y_{i} \cdot \sin \left(2 \pi \cdot \frac{i}{T}\right), \\
& k_{c}=\frac{2}{n} \cdot \sum_{i=1}^{n} y_{i} \cdot \cos \left(2 \pi \cdot \frac{i}{T}\right) .
\end{aligned}
$$

The essence of the method is finding the periodic function iteratively by changing the return time. The correspondence of the trend-free data series and the specified periodic function shall be precise enough. Finally the values of the functions were calculated, which describe the original observed karst water level data series. These certain values could be specified by the sum of the coherent trend and the periodic components:

$$
Y_{i}=T_{i}+P_{i}
$$

The periodic daily water level fluctuation of the three investigated karst water level series mathematically can be described by the following formulas:

$$
\begin{aligned}
& Y_{i, \text { Tata-Pokol }}=137.11-10^{-3} \cdot i+0.023 \cdot \sin \left(2 \pi \frac{i}{12}\right)-0.034 \cdot \cos \left(2 \pi \frac{i}{12}\right), \\
& Y_{i, \text { Kocs }-1}=136.98-10^{-3} \cdot i+0.019 \cdot \sin \left(2 \pi \frac{i}{12}\right)-0.033 \cdot \cos \left(2 \pi \frac{i}{12}\right), \\
& Y_{i, \text { Malom-tó }}=103.14+10^{-5} \cdot i-10^{-4} \cdot \sin \left(2 \pi \frac{i}{12}\right)-0.006 \cdot \cos \left(2 \pi \frac{i}{12}\right)
\end{aligned}
$$

According to the functions of the short-term water level fluctuation the following can be stated:

- Water level series of the monitoring wells called 'Tata-Pokol' and 'Kocs-1' belonging to the same karst aquifer showed decreasing trend during the selected three-day interval. The calculated water levels followed each other in parallel with $13 \mathrm{~cm}$ constant distance; 
- Water levels of 'Malom-lake' situated in the Molnár János-Cave in Budapest were stagnant in the period mentioned above. The altitude of observed karst water levels were significantly different from data series of the other two monitoring wells (they represent another karst aquifer system);

- There is a significant difference between the amplitude of periodic functions, which describe mathematically the water level fluctuation of karst aquifers. Nevertheless the return time is 12 hours in both cases and the local minimum and maximum values arise at the same time alternating every 6 hours.

Fig. 7 shows observed raw water level data series of the three investigated monitoring wells. The graph also draws the calculated trend lines and the curve of the specified periodic functions. Because of the different altitudes and different amplitudes we applied a secondary vertical axis the scale of which was ten times greater than the scale of the primary axis.

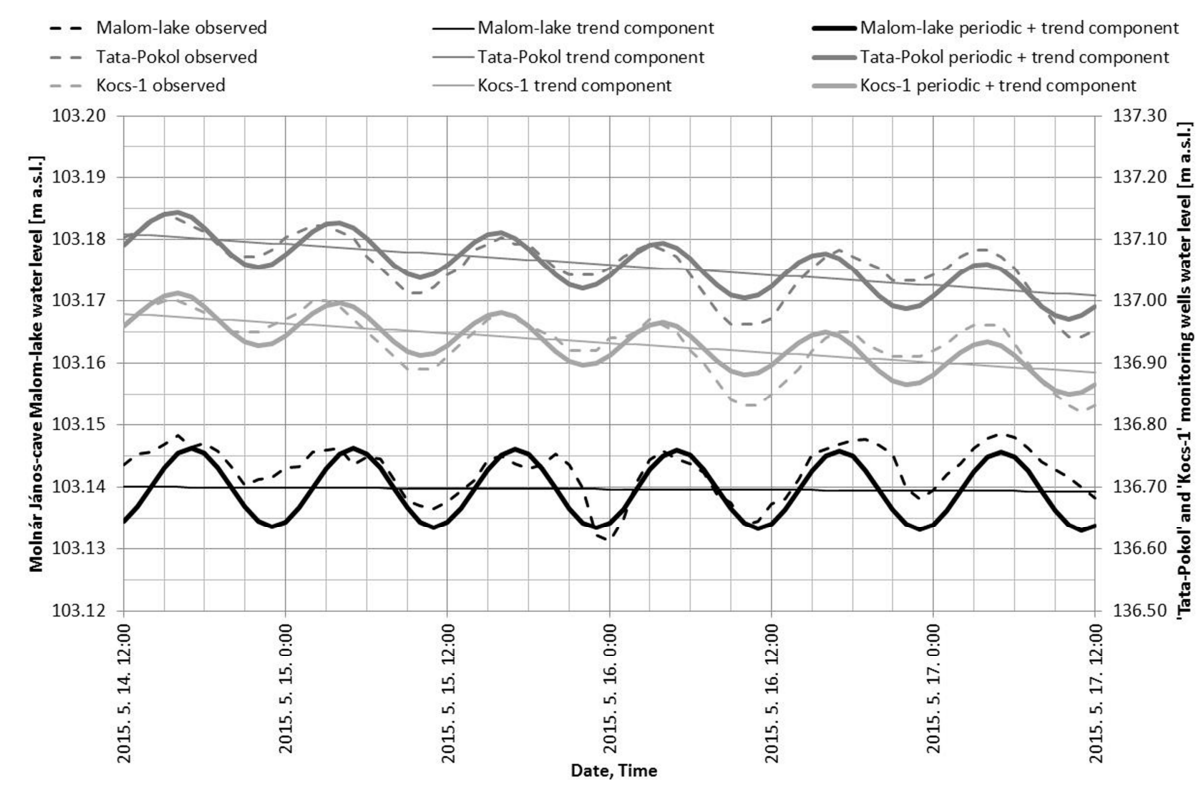

Fig. 7. Comparison of daily water level fluctuation in different karst aquifers

The dynamics of short-term water level fluctuation was the same in the examined data series but the amplitude of periodic curve of Malom-lake was different from the other values (of the monitoring wells situated near Tata). This means that tidal and barometric effects can be identified in water levels of different karst aquifers but the level magnitude of fluctuations is significantly different. The result of the investigation presented in this paper can be confirmed by the observation of Maucha [14] who specified the periodic daily fluctuation at $2-3 \mathrm{~cm}$ based on karst water level data series of Jósvafó Research Station. This scale of alteration is approximately equals to periodic 
water level alterations observed in Molnár János Cave, but an order of magnitude slighter than the fluctuation registered in the Tatabánya-basin.

\section{Further development of the investigation}

In connection with the quantitative analysis of karst aquifers among others the current state of monitoring system should be improved in the region of Tata as a longerterm development of the related research. Nowadays in case of certain karst water level monitoring wells, updated data series are not available because the piezometric pressure level is several meters above the ground surface. It is necessary to equip about 4-5 monitoring wells with water level recorder. Measuring water discharges of the returning or recently appeared karst springs have high importance because spring discharge data series are going to be the basic data during planning systems for the drainage or utilization of karst water. For this reason a comprehensive karst water discharge monitoring system shall be established. It is necessary to modify the drainage system near 5 springs in Tata in order to water discharges become measurable.

The assessment of short-term water level fluctuation should be expanded. The above evaluated periodic daily changes can be analyzed in water level data series of other Hungarian karst systems (e.g. Aggtelek Karst) as well. Besides it would like to be verified through an international example that this phenomenon is general in any karst aquifers. Another development opportunity of this part of the research is the expansion of short-term analysis for periodic fluctuation of spring water discharges, though this also depends on the development of monitoring system and the available instruments. The short-term alteration of spring water discharges can be detected only by the help of high precision observation technology and continuous registration

\section{Conclusions}

In the paper large-scale water level alterations of karst aquifers were analyzed, which were observed in the underground water system of Transdanubian Range during the last 50 years. The long-term analysis resulted in regressive velocity of recharge, therefore the recharging process of the karst aquifer was getting slower. This is similar to the result of an ordinary short-term pumping test. According to the available data of different monitoring wells it was presented that the piezometric pressure difference which ensured the underground flow of karst water in the region - was equalized by the beginning of the $1980 \mathrm{~s}$.

During the assessment of short-term water level fluctuations not only data series of the monitoring wells of Tata region were analyzed but also water level series of another karst aquifer situated in Budapest. According to the hydrological analysis it is stated that tidal and barometric effects can be identified in water levels of different karst aquifers but the level magnitude of fluctuations is significantly different. The features of daily periodic alteration depend on the structure (storage properties) of the different aquifers. Besides, the tidal effect and the barometric pressure influence differently the groundwater fluctuations at certain locations. Defining the relationship between the tidal 
efficiency, barometric efficiency and the storage properties of the aquifer requires further investigations.

\section{Acknowledgements}

Special thanks are given by the authors to the North-Transdanubian Water Directorate for the data service.

\section{References}

[1] Haas J., Lukoczki G., Budai T., Demény A. Genesis of upper Triassic peritidal dolomites in the Transdanubian Range, Hungary, Facies, Vol. 61, No. 8, 2015, doi: 10.1007/s10347015-0435-7

[2] Haas J. Characteristics of peritidal facies and evidences for subaerial exposures in Dachstein-type cyclic platform carbonates in the Transdanubian Range, Hungary, Facies, 2004, Vol. 50, No. 2, 2004, pp. 263-286.

[3] Haas J., Budai T., Demény A. Partial dolomitization of foreslope and toe-of-slope facies of a Carnian carbonate platform, Transdanubian Range, Hungary, Central European Geology, Vol. 57, No. 1, 2014, pp. 1-19.

[4] Kumánovics Gy. Karst water management in the region of Transdanubian, (in Hungarian) Vizügyi Közlemények, Vol. 80, No. 2, 1998, pp. 229-244.

[5] Karay Gy., Szilágyi M., Hajnal G. Determination of the transmissivity of a karstified aquifer from mine dewaters data, Pollack Periodica, Vol. 11, No. 3. 2016, pp. 105-118.

[6] Eördöghné Miklós M. Characteristics of the aquifer from the perspective of the water services, Pollack Periodica, Vol. 9, No. 1, 2014. pp. 113-120.

[7] Mádl-Szőnyi J., Tóth Á. Basin-scale conceptual groundwater flow model for an unconfined and confined thick carbonate region, Hydrogeology Journal, Vol. 23, No. 7, 2015, pp. 1359-1380.

[8] Gerber P. The process of mine dewatering in Tatabánya and its effects on the water levels of the region, (in Hungarian) Tatabányai Bányák Vállalat, Tatabánya, 1989.

[9] Investigations and action plan in connection with the return of springs in Tata, Tata Város Önkormányzata, Tata, 1999.

[10] Szilágyi M., Maller M., Hajnal G. Analysis of karst water level forecasts in the Tata region, (in Hungarian) Mérnökgeológia-Közetmechanika,2015. pp. 41-50.

[11] Gerber P. Karst hydrogeological observations related to the western upthrust of the Tatabánya-basin, (in Hungarian) V. Bányavizvédelmi Konferecia, Budapest, Hungary, 1965, pp. 74-95.

[12] Goldscheider N., Mádl-Szőnyi J., Erőss A., Schill E. Review: Thermal water resources in carbonate rock aquifers, Hydrogeology Journal, Vol. 18, No. 6, 2010, pp. 1303-1318.

[13] Kontur I., Koris K., Winter J. Hydrological calculations, (in Hungarian) Lecture notes, Linograf, 2003, pp. 149-169.

[14] Maucha L. The effect of atmospheric pressure on the alteration of spring water discharges, (in Hungarian) Karsztfejlödés, Vol. XIII, 2008, pp. 61-73. 